\title{
Pengaruh Modal Terhadap Omset Pada Pelaku UMKM di Seluruh Kecamatan Pekanbaru
}

\author{
DEWI SARTIKA \\ Akademi Sekretari dan Manajemen Persada Bunda \\ Jl.Diponegoro No.42 Pekanbaru \\ Email :dewiarelagha@gmail.com
}

\begin{abstract}
The study consists of two variables: the independent variable (X) is the capital and the dependent variable (Y) is turnover of capital. Data used in this study is qualitative data and source data used is secondary data. This research analyzed with simple linear regression, using t-test dan the coefficient of determination by using SPSS vers 17. The results of this research indicate that there is significant influence on the turnover of capital to SMEs in all districts Pekanbaru
\end{abstract}

Keywords: capital, turnover of capital

Usaha Mikro Kecil Menengah (UMKM) sekarang ini sangat digalakkan oleh pemerintah. Hal ini bukan tanpa sebab. Karena dari sekian banyak jumlah usaha yang produktif yang ada di Indonesia, sekitar 98,88 \% usaha di Indonesia berupa UMKM dan produk UMKM mampu menyumbang $33 \%$ dari total produk domestik Indonesia. Hal ini menunjukkan pentingnya peran usaha mikro kecil menengah di Indonesia.

Begitu juga di Provinsi Riau. Pertumbuhan ekonomi yang tinggi di Riau, membuat UMKM memegang peranan penting. Jumlah UMKM di provinsi Riau dari tahun 2007-2015 mengalami pertumbuhan yang pesat. Hal ini juga menunjukkan bahawa UMKM sangat potensial untuk dijalankan.

Adapun jenis usaha yang dilakukan atau dibangun oleh pelaku UMKM sangat bervariasi. Kegiatan usaha UKM mencakup berbagai macam kegiatan di bidang usaha antara lain usaha di sektor pertanian, pertambangan dan penggalian, industri pengolahan, konstruksi, perdagangan hotel restoran, keuangan dan sewa serta jasa-jasa lainnya. Ketahanan usaha ini disebabkan struktur keuangan tidak banyak tergantung pada perbankan walaupun usaha mikro tetap memanfaatkan jasa perbankan, baik untuk transaksi maupun menjaga keamanan.

Dibalik besarnya peranan UMKM di Provinsi Riau bagi perekonomian kita, salah satu hambatan terbesar dalam mengembangkan UKM adalah sulitnya memperoleh modal. Kendala permodalan menjadi yang utama (40.48\%) dari keseluruhan kendala (Kementerian Negara Koperasi dan UKM 2012). Modal merupakan salah satu faktor yang paling berperan dalam kegiatan usaha yang nantinya akan mempengaruhi omset usaha.

Modal merupakan salah satu bagian terpenting yang harus dimiliki oleh setiap perusahaan. Dengan modal, sebuah perusahaan dapat melaksanakan aktivitas produksi dan aktivitas-aktivitas bisnis lainnya. Tanpa modal (yang berbentuk uang), sebuah perusahaan tetap dapat berjalan, namun aktivitasnya akan sangat terbatas. Apabila perusahaan menghadapi kekurangan modal, perusahaan akan mengalami berbagai permasalahan seperti masalah dalam menjalankan usaha seharihari,kesulitan dalam mengembangkan usaha, kesusahan menarik investor.

Besarnya modal tergantung pada komoditas usaha. Pemenuhan modal usaha tidak hanya berasal dari uang pribadi pengusaha, namun dari eksternal 
seperti pinjaman kepada kerabat atau lembaga keuangan seperti bank. Tanpa modal yang cukup, pengusaha tidak bisa memenuhi kebutuhan untuk menjalankan usaha. Bila dengan modal sendiri kurang mencukupi untuk mengembangkan usaha, UMKM bisa mencari sumber dananya dari luar atau disebut dengan modal asing. Modal asing dapat bersumber dari pinjaman dari bank, lembaga keuangan lainnya. Dengan adanya penambahan modal diharapkan dapat meningkatkan usaha yang nantinya dapat meningkatkan omzet usaha itu sendiri. Dalam penelitian ini UMKM yang diteliti adalah UMKM yang sudah memiliki izin usaha yaitu IUMK.

Modal merupakan salah satu faktor terpenting dari kegiatan produksi. Bagi perusahaan yang baru berdiri atau mulai menjalankan usahanya, modal digunakan untuk menjalankan usahanya, sedangkan bagi perusahaan atau bidang usaha maupun bisnis yang sudah berdiri lama, modal biasanya digunakan untuk dapat mengembangkan usaha maupun memperluas pangsa pasar dari bisnis dan usaha tersebut.

Menurut Prawirosentono (2002 dalam Neti, 2009) modal merupakan kekayaan yang dimiliki perusahaan yang dapat menghasilkan keuntungan pada waktu yang akan datang dan dinyatakan dalam nilai uang. Modal dalam bentuk uang. Pada suatu usaha mengalami perubahan bentuk sesuai dengan kebutuhan untuk mencapai tujuan usaha yaitu sebagian dibelikan tanah dan bangunan,sebagian dibelikan persediaan bahan, sebagian dibelikan mesin dan peralatan, dan sebagian disimpan dalam bentuk uang tunai.

Menurut Tulus (2013) menjelaskan bahwa modal adalah salah satu faktor produksi yang sangat penting bagi setiap usaha, baik skala kecil, menengah maupun besar.

Menurut Kamus Besar Bahasa Indonesia dalam Arinda (2014) omset merupakan total jumlah penjualan barang atau jasa selama periode penjualan tertentu. Omset yang besar tidak selalu mendapatkan keuntungan yang besar.

Modal yang digunakan ketika menjalankan usaha berasal dari dua sumber yaitu modal internal dan modal eksternal. Modal internal adalah modal yang diperoleh dari laba yang ditahan, sedangkan modal eksternal merupakan pinjaman dari pihak luar.

Menurut Mardiyatmo (2008), modal sendiri merupakan modal yang diperoleh dari pemilik usaha itu sendiri baik berupa tabungan, sumbangan, hibah, dan lain sebagainya. Modal sendiri mempunyai kelebihan seperti tidak bergantung kepada orang lain, tidak memerlukan persyaratan, dan tidak adanya keharusan pengembalian modal. Sedangkan kelemahan dalam modal sendiri adalah jumlahnya terbatas, membutuhkan waktu yang relatif lama untuk mengumpulkan uang, dan kurangnya motivasi pengusaha.

Modal asing atau modal pinjaman merupakan modal yang diperoleh dari pihak luar pengusaha berupa pinjaman. Modal pinjaman mempunyai jumlah yang tidak terbatas, artinya pengusaha mikro dapat dengan mudah mengembangkan usahanya.

Omset adalah nilai transaksi yang terjadi dalam hitungan waktu tertentu, misalnya harian, mingguan, bulanan, tahunan. Omset adalah seluruh jumlah uang yang didapat dari hasi lpenjualan dalam jangk awaktu tertentu namun belum dikurangi dengan biaya HPP (HargaPokokProduksi, bahan baku ,peralatan dll ) dan Expense (Gaji karyawan gaji diri anda sendiri, peralatan, tagihan listrik, biaya iklan biaya pemasaran, biaya distribusi, biay atempat, biaya transportasi biaya komunikasi.

Chaniago (2012) memberikan pendapat tentang omzet penjualan adalah keseluruhan jumlah pendapatan yang didapat dari hasil penjualan suatu barang/jasa dalam kurun waktu tertentu. 
Menurut Swastha (2010) memberikan pengertian omset adalah akumulasi dari kegiatan penjualan suatu produk barang dan jasa yang dihitung secara keseluruhan selama kurun waktu tertentu secara terus menerus.

Menurut Swasta (2010:122) faktorfaktor yang mempengaruhi omset/penjualan adalah: 1) Kondisi dan Kemampuan Penjual. Penjual harus dapat meyakinkan kepada pembelinya agar dapat berhasil mencapai sasaran penjualan yang diharapkan. Untuk itu penjual harus memahami beberapa hal yaitu jenis dan karakteristik barang yang ditawarka, harga produk dan syarat penjualan. 2). Kondisi Pasar. Pasar sebagai kelompok pembeli atau pihak yang menjadi sasaran dalam penjualan, dapat pula mempengaruhi kegiatan penjualan. Adapun faktor kondisi pasar yang perlu diperhatikan adalah jenis pasar, kelompok pembeli, daya belinya, frekuensi pembeliannya, dan keinginan serta kebutuhannya. 3).Modal. Modal merupakan penunjang bagi terlaksananya kegiatan pejualan. 4). Kondisi Organisasi Perusahaan. Pada perusahaan besar biasanya masalah penjualan ini ditangani oleh bagian tersendiri. Yang dipegang oleh orang-orang tertentu atau ahli dalm bidang penjualan, sedangkan dalam perusahaan kecil biasanya masalah penjualan masih ditangani oleh orang yang juga melaksanakan fungsi-fungsi lainnya. 5). Faktor-Faktor Lainnya. Faktor lainnya yang mempengaruhi omzet adalah periklanan, kampanye, diskon, dan pemberian hadiah.

Menurut Undang undang Republik Indonesia pada Dinas Koperasi dan UKM tahun 2008 bab IV pasal 6, Kriteria usaha mikro adalah a). memiliki kekayaan bersih paling banyak Rp.50.000.000 (lima puluh juta rupiah) tidak termasuk tanah dan bangunan tempat usaha atau b). memiliki hasil penjualan tahunan paling banyak Rp.300.000.000 (tiga ratus juta rupiah)

Sedangkan kriteria usaha kecil adalah: a). memiliki kekayaan bersih lebih dari Rp.50.000.000 (lima puluh juta rupiah) sampai dengan paling banyak
Rp.500.000.000 (lima ratus juta rupiah) tidak termasuk tanah dan bangunan tempat usaha atau b). memiliki hasil penjualan tahunan lebih dari Rp.300.000.000 (tiga ratus juta rupiah) sampai dengan paling banyak Rp.2.500.000 (dua milyar lima ratus juta rupiah.Sedangkan kriteria usaha menengah adalah : a). memiliki kekayaan bersih lebih dari Rp.500.000.000 (lima ratus juta rupiah) sampai dengan paling banyak Rp.10.000.000.000 (sepuluh milyar) tidak termasuk tanah dan bangunan tempat usaha atau b). memiliki hasil penjualan tahunan lebih dari Rp.2.500.000 (dua milyar lima ratus juta rupiah) sampai dengan paling banyak Rp.50.000.000.000 (lima puluh milyar).

\section{METODE}

Penelitian ini dilakukan di UMKM yang ada di seluruh kecamatan Pekanbaru. Penelitian ini dilakukan dari bulan Februari-Agustus 2017. Populasi menurut Sugiyono (2014:148) adalah wilayah generalisasi yang terdiri atas objek atau subjek yang mempunyai kuantitas dan karakteristik tertentu yang ditetapkan oleh peneliti untuk dipelajari dan kemudian ditarik kesimpulannya. Populasi dalam penelitian ini adalah seluruh pelaku UMKM yang sudah memiliki IUMK yang ada di seluruh Kecamatan Pekanbaru yang berjumlah 765 orang.

Menurut Sugiyono (2014:149) sampel ialah bagian dari jumlah dan karakteristik yang dimiliki oleh populasi tersebut. Dalam penelitian ini seluruh anggota populasi juga merupakan anggota sampel. Metode pengambilan sampel seperti ini disebut dengan metode sensus. Sehingga jumlah sampel sebanyak 765 orang.

Variabel adalah suatu atribut atau sifat atau nilai dari orang, objek atau kegiatan yang mempunyai variasi tertentu yang ditetapkan oleh peneliti untuk dipelajari dan ditarik kesimpulannya (Sugiyono, 2007:2). Penelitian ini menggunakan dua variabel yaitu:Variabel 
dependen adalah variabel yang menjadi pusat perhatian utama peneliti. Hakekat sebuah masalah mudah terlihat dengan mengenali berbagai variabel dependen yang digunakan dalam sebuah model. Variabilitas dari atau atas faktor inilah yang berusaha untuk dijelaskan oleh seorang peneliti. Dalam penelitian ini yang menjadi variabel dependen adalah omset (Y).

Variabel Independen yang dilambangkan dengan $\mathrm{X}$ adalah variabel yang mempengaruhi variabel dependen, baik yang pengaruhnya positif maupun yang pengaruhnya negative.Variabel independen dalam penelitian ini adalah modal.

Jenis data yang digunakan dalam penelitian ini adalah data kuantitatif yaitu data yang dapat diinput ke dalam skala pengukuran statistik. Fakta dan fenomena dalam data ini tidak dinyatakan dalam bahasa alami, melainkan dalam numerik.

Adapun sumber data yang digunakan adalah data sekunder: merupakan data yang diperoleh secara tidak langsung, baik berupa keterangan maupun literature yang ada hubungannya dengan penelitian. Data yang digunakan dalam penelitian ini berupa informasi perkembangan UMKM di Pekanbaru Kota, informasi identitas pelaku UMKM, modal, omset,dan IUMK pelaku UMKM.

Metode pengumpulan data yang digunakan dalam penelitian ini adalah dokumentasi yaitu dengan mengumpulkan informasi melalui jurnal, literature, buku, laporan, dan referensi yang berkaitan dengan penelitian ini dan penelitian terdahulu yang berkaiatn dengan penelitian yang sedang dilakukan.

Regresi linier sederhana didasari hubungan fungsional maupun kausal dari satu variabel independen dengan satu variabel dependen. Analisis regresi linier sederhana adalah mencari hubungan linier antara kedua variabel yaitu arah hubungan positif atau negative dan memprediksi nilai dari variabel dependen bila nilai independen mengalami kenaikan atau penurunan dengan menyertakan bilangan konstanta yang telah ditentukan besarya. Persamaan regresi linier sederhana yaitu:

$\mathrm{Y}=\mathrm{a}+\mathrm{bX}$

Dimana

$\mathrm{a}=$ konstanta dari persamaan regresi

$\mathrm{b}=$ koefisien regresi dari variabel $\mathrm{X}$ (modal)

$\mathrm{X}=$ modal

$\mathrm{Y}=$ omset

Uji t digunakan untuk menguji pengaruh variabel independen yang digunakan dalam penelitian ini secara individual dalam menerangkan variabel dependen secara parsial, Ghozali (2012:98). Adapun kriteria uji t yaitu:

a. Apabila $\mathrm{t}$ hitung $>\mathrm{t}$ tabel dan tingkat signifikansi $<\alpha(0,05)$, maka variabel independen secara individual berpengaruh terhadap variabel dependen.

b. Apabila $\mathrm{t}$ hitung $<\mathrm{t}$ tabel dan tingkat signifikansi $>\alpha(0,05)$, maka variabel independen secara individual tidak berpengaruh terhadap variabel dependen.

\section{HASIL}

Berdasarkan hasil pengumpulan data sekunder yang diperoleh dari Dinas Koperasi dan UKM di seluruh kecamatan Pekanbaru berupa data modal dan omset para pelaku UMKM yang sudah memiliki IUMK, maka diperoleh persamaan regresi linier sederhana, uji $t$ dan koefisien determinasi $\left(\mathrm{R}^{2}\right)$.

\section{Regresi Linier Sederhana}

Untuk mengetahui hubungan antara modal terhadap omset pada pelaku UMKM di seluruh kecamatan Pekanbaru, maka didapat persamaan regresi linier sederhana yaitu

Tabel 1 Regresi Linier Sederhana

Coefficients $^{\mathrm{a}}$

\begin{tabular}{|c|c|c|c|c|c|}
\hline \multirow[b]{2}{*}{ Model } & \multicolumn{2}{|c|}{$\begin{array}{l}\text { Unstandardized } \\
\text { Coefficients }\end{array}$} & \multirow{2}{*}{\begin{tabular}{|l}
$\begin{array}{l}\text { Standardized } \\
\text { Coefficients }\end{array}$ \\
Beta
\end{tabular}} & \multirow[b]{2}{*}{$\mathrm{t}$} & \\
\hline & B & Std. Error & & & Sig. \\
\hline (Constant) & 6.994E7 & 4670667.448 & & 14.975 & .000 \\
\hline Modal & .723 & .070 & .350 & 10.273 & .000 \\
\hline
\end{tabular}

a. Dependent Variable: omze

Berdasarkan tabel 1 diperoleh persamaan 
regresi linier sederhana yaitu

$$
\mathrm{Y}=6,994 \times 10^{7}+0,723 \mathrm{X}
$$

Dimana

$\mathrm{a}=6,994 \times 10^{7}$ yang berarti apabila modal tidak ada maka omzet sebesar 6,994 x $10^{7}$

$\mathrm{b}=0,723$ merupakan koefisien regresi yang bernilai positif. Hal ini menunjukkan bahwa apabila modal meningkat satu satuan maka omzet akan bertambah sebesar 0,723.

\section{Uji t}

Uji t digunakan untuk melihat pengaruh modal terhadap omset pada pelaku UMKM secara parsial.

Tabel 2 Uji $t$

Coefficients $^{\mathrm{a}}$

\begin{tabular}{|c|c|c|c|c|c|}
\hline \multirow[b]{2}{*}{ Model } & \multicolumn{2}{|c|}{$\begin{array}{l}\text { Unstandardized } \\
\text { Coefficients }\end{array}$} & \multirow{2}{*}{\begin{tabular}{|l}
$\begin{array}{l}\text { Standardized } \\
\text { Coefficients }\end{array}$ \\
Beta
\end{tabular}} & \multirow[b]{2}{*}{$\mathrm{t}$} & \multirow[b]{2}{*}{ Sig. } \\
\hline & B & Std. Error & & & \\
\hline (Constant) & 6.994E7 & 4670667.448 & & 14.975 & .000 \\
\hline Modal & .723 & .070 & .350 & 10.273 & .000 \\
\hline
\end{tabular}

Berdasarkan tabel 2 terlihat bahwa nilai $\mathrm{t}$ hitung sebesar 10,273 dan signifikan sebesar 0,00 . Yang berarti bahwa terdapat pengaruh signifikan antara modal terhadap omset pada pelaku UMKM di seluruh kecamatan Pekanbaru.

\section{Koefisien Determinasi $\left(\mathrm{R}^{2}\right)$}

Koefisien determinasi digunakan untuk mengetahui besarnya kontribusi/sumbangan variabel modal terhadap omset pada pelaku UMKM di seluruh kecamatan Pekanbaru.

Tabel 3 Koefisien Determinasi

Model Summary

\begin{tabular}{|l|l|l|l|l|l|}
\hline Model & $\mathrm{R}$ & $\begin{array}{l}\mathrm{R} \\
\text { Square }\end{array}$ & $\begin{array}{l}\text { Adjusted } \\
\text { Square }\end{array}$ & $\begin{array}{l}\text { Std. Error of the } \\
\text { Estimate }\end{array}$ \\
\hline 1 & $.350^{\mathrm{a}}$ & .122 & .121 & $1.20257 \mathrm{E} 8$ \\
\hline
\end{tabular}

a. Predictors: (Constant), modal

Berdasarkan tabel 3 terlihat bahwa koefisen determinasi $\left(\mathrm{R}^{2}\right)$ sebesar 0,122 atau $12,2 \%$. Hal ini menunjukkan bahwa kontribusi modal terhadap omzet sebesar $12,2 \%$.

\section{PEMBAHASAN}

Berdasarkan persamaan regresi linier sederhana diperoleh hubungan yang positif antara modal dengan omset pada pelaku Jurnal Daya Saing (Vol. 4, No. 2 Jun 2018)
UMKM di seluruh kecamatan Pekanbaru. Hal ini menunjukkan bahwa apabila terjadi peningkatan modal akan meningkatkan omset pada pelaku usaha UMKM di seluruh kecamatan Pekanbaru.

Begitu juga dengan hasil uji t, terdapat pengaruh signifikan antara modal terhadap omset pada pelaku UMKM di seluruh kecamatan Pekanbaru. Dan berdasarkan hasil koefisen determinasi menunjukkan bahwa modal memberikan kontribusi terhadap omzet pada pelaku usaha UMKM di seluruh kecamatan Pekanbaru.

Hasil penelitian ini sejalan dengan penelitian yang dilakukan Rahman, F. (2017) bahwa modal memiliki kaitan dengan produksi.

\section{SIMPULAN}

Berdasarkan uraian bab-bab sebelumya, dapat ditarik kesimpulan sebagai berikut: Berdasarkan persamaan regresi linier terdapat hubungan yang positif antara modal dengan omset pada pelaku UMKM di seluruh kecamatan Pekanbaru. Berdasarkan uji $t$ terdapat pengaruh signifikan antara modal terhadap omzet pada pelaku UMKM di seluruh kecamatan Pekanbaru. Kontribusi modal terhadap omset tidak tinggi.

\section{DAFTAR RUJUKAN}

Arinda,Rengganis. 2014. Analisis Pengaruh Modal Awal Terhadap Omset Usaha Mikro di Dramaga, Bogor.

Chaniago,A. 2015. Ekonomi 2. Bandung: Angkasa

Ferdinan, Augusty.2006. Metode Penelitian Manajemen: Pedoman Penelitian untuk Skripsi, Tesis dan Disertasi. Semarang: Universitas Diponegoro

Fitanto B. 2009. Analisis Omset dan Posisi Bersaing Pada Klaster Usaha Kecil Menengah (UKM) Sepatu Kota Mojokerto [jurnal]. Journal

p.ISSN: 2407-800X e.ISSN: 2541-4356 
of Indonesian Applied Economics.

Vol 3 No 1. Mei 2009 23-36

Nyoto. 2015. Metode Penelitian Teori dan Aplikasi.Riau :UR Pres

Priyatno, Dwi. 2016. SPSS Handbook. Yogyakarta: Mediakom

Rahman, F. (2017). Peran Modal Manusia Dan Modal Investasi Terhadap Nilai Produksi Industri Kecil Di Kota Pekanbaru. Jurnal Benefita, 2(1), 1-9.

Sugiyono. 2014. Metode Penelitian Manajemen. Bandung:Alfabeta

Swastha, Basu, dan Irawan. 2005. Manajemen Pemasaran Modern. Yogyakarta: Liberty 